\title{
Evaluasi Penggunaan Pendekatan Saintifik di dalam Pembelajaran Siswa Sekolah Dasar
}

\author{
Juwairiah \\ Politeknik Negeri Media Kreatif PSDKU Medan \\ *Penulis korespondensi: juwairiah@polimedia.ac.id \\ DOI : https://doi.org/10.21580/jieed.v1i2.7717 \\ Received: 2021-02-26, Revised: 2021-05-06, \\ Accepted: 2021-11-06, Published: 2021-11-06
}

\begin{abstract}
Abstrak
Penelitian ini bertujuan untuk mengevaluasi kesesuaian rencana pembelajaran guru, kesesuaian pembelajaran dengan rencana pembelajaran guru, kelengkapan unsur-unsur pendekatan saintifik di dalam proses pembelajaran, kendala guru dalam menerapkan pendekatan saintifik, dan strategi guru dalam mengatasi kendala penerapan pendekatan saintifik. Penelitian ini dilaksanakan dengan menggunakan metode penelitian deskriptif kuantitatif. Teknik pengumpulan data penelitian ini adalah observasi, angket, wawancara, dan dokumentasi. Hasil penelitian ini menunjukkan bahwa: (1) kesesuaian RPP guru dibandingkan dengan kriteria RPP Kurikulum 2013 berada dalam kategori baik dengan persentase sebesar 86,41\% (2) kesesuaian proses pembelajaran dengan rencana program pembelajaran berada dalam kategori baik dengan presentase 82\%; (3) kelengkapan unsur-unsur pendekatan saintifik di dalam proses pembelajaran tergolong kurang dengan presentase 48\%; (4) kendala guru dalam menerapkan pendekatan saintifik adalah dalam melaksanakan kegiatan asosiasi, yaitu berada dalam kategori kurang dengan presentase 7\%; (5) strategi guru dalam mengatasi kendala penerapan kegiatan asosiasi adalah dengan melatih siswa untuk memecahkan masalah, memfasilitasi siswa dengan media pembelajaran; memberikan reward, menyediakan sumber belajar tambahan, dan mendorong siswa untuk berdiskusi dengan teman sekelasnya.
\end{abstract}

Kata Kunci: pendekatan saintifik, pembelajaran ilmu pengetahuan alam, pembelajaran IPA di sekolah dasar, kualitas pembelajaran saintifik 


\title{
Evaluation of the Use of Scientific Approach in Learning \\ of Elementary School Student
}

\begin{abstract}
This study aims to evaluate the suitability of the teacher's lesson plan, the suitability of learning with the teacher's lesson plan, the completeness of the elements of the scientific approach in the learning process, the obstacles of the teacher in applying the scientific approach, and the teacher's strategy in overcoming the obstacles to the application of the scientific approach. This research was conducted using quantitative descriptive research methods. The data collection techniques of this study were observation, questionnaires, interviews, and documentation. The results of this study indicate that: (1) the suitability of the teacher's RPP compared to the 2013 curriculum RPP criteria is in the good category with a percentage of $86.41 \%$ (2) the suitability of the learning process with the learning program plan is in the good category with a percentage of 82\%; (3) the completeness of the elements of the scientific approach in the learning process is classified as lacking with a percentage of 48\%; (4) the teacher's obstacle in applying the scientific approach is in carrying out association activities, which are in the less category with a percentage of 7\%; (5) the teacher's strategy in overcoming obstacles to the application of association activities is to train students to solve problems, facilitate students with learning media; provide rewards, provide additional learning resources, and encourage students to discuss with their classmates.
\end{abstract}

\section{Keywords: scientific approach, natural science learning, science learning in elementary schools, scientific learning quality}

\section{PENDAHULUAN}

Kurikulum 2013 merupakan kurikulum yang diberlakukan untuk menggantikan kurikulum tingkat satuan pendidikan (KTSP). Penerapan kurikulum 2013 menerapkan pendekatan saintifik (scientific approach), yaitu pembelajaran yang terdiri atas lima langkah, yaitu: mengamati, menanya, mengumpulkan informasi, menguji atau menalar, dan mengkomunikasikan (Andriani, 2018).

Penyusunan Rencana Pelaksanaan Pembelajaran (RPP) Kurikulum 2013 revisi 2017 harus muncul empat macam hal, yaitu: 1) Penguatan Pendidikan Karakter (PPK) didalam pembelajaran,2) Literasi, 3) 4C (Creative, Critical thinking, Communicative, dan Collaborative), dan 4) Higher Order Thinking Skill (HOTS) sehingga perlu kreatifitas guru dalam meramunya. Dalam kurikulum 2013 revisi 2017, langkah pembelajaran yang mengacu pada 5M (Mengamati, Menanya, Menguji, Menalar, dan Mengkomunikasikan) masih tetap ditanamkan (Mahardikanews, 2013). 
Pendekatan saintifik dalam pembelajaran sebagaimana dimaksud meliputi mengamati, menanya, mencoba, mengolah, menyajikan, menyimpulkan, dan mencipta (Mudana, 2020). Kurikulum 2013, dilaksanakan melalui pendekatan scientific, dengan lima aspek yang terdiri dari mengamati, menanya, mencoba, menalar dan komunikasi. Lima aspek ini harus terealisasi pada proses pembelajaran. Guru harus berupaya untuk mengorganisasikan kerjasama dalam kelompok belajar, melatih siswa berkomunikasi sehingga siswa menemukan konsep, dan hasil dari penyelesaian masalah, serta prinsip yang didapat melalui proses belajar, oleh karena itu desain media yang digunakan dalam implementasi kurikulum 2013 harus memuat langkah-langkah pendekatan scientific agar tujuan pembelajaran dapat tersampaikan dengan efektif (Saputra, 2021).

Hasil penelitian Aeni,dkk (2016) ditemukan, bahwa guru masih mengalami kesulitan dalam menerapkan pendekatan berbasis saintifik (5M). Seillariski (2015), melaporkankendala yang dihadapi guru adalah kurangnya pemahamandan persiapanguru terkait dengan pendekatan saintifik sehingga proses pembelajaran dengan pendekatan saintifik belum berjalan maksimal.

Hasil analisis data penelitian yang dilakukan (Nureva \& Melinda, 2021), diperoleh hasil bahwa adanya pengaruh pendekatan saintifik terhadap hasil belajar ilmu pengetahuan alam peserta didik kelas V. Hal ini dibuktikan dengan adanya peningkatan hasil belajar peserta didik pada nilai rata-rata posttest $(85,37)$ peserta didik yang tergolong lebih besar daripada nilai rata-rata pretest $(65,00)$.

Sementara, proses pembelajaran harapannya dapat dilaksanakan sesuai dengan tuntutan kurikulum yang berlaku. Pada kurikulum 2013, pendekatan saintifik (saintific approuch) dipandang salah satu pendekatan yang sangat ditekankan untuk dilaksanakan oleh guru karena pendekatan saintifik dipercaya sebagai upaya dalam mengembangkan prilaku, keahlian, dan pengetahuan peserta didik. Pendekatan saintifik juga diyakini hasilnya lebih baik dari pembelajaran konvensional (Suratno, 2020).

Dari awal perubahan kurikulum yang pernah di alami SDN 060849 Medan sampai saat ini menerapkan Kurikulum 2013 revisi 2017 sesuai ketetapan kementerian, pelaksanaan penerapan Kurikulum 2013 yang di dalamnya menerapkan pendekatan saintifik (scientific approach) pada saat proses pembelajaran IPA disekolah tersebut belum pernah di evaluasi, demikian jawaban hasil wawancara yang dilakukan oleh Peneliti dengan Kepala Sekolah SDN 060849 Medan.

Dengan menggunakan strategi yang bervariasi akan mengurangi tingkat kebosanan siswa dan akan meningkatkan minat siswa dalam belajar. Ilmu Pengetahuan Alam (IPA) adalah mata pelajaran yang wajib di ajarkan di sekolah. Pembelajaran IPA merupakan studi tentang mahluk hidup atau studi tentang masalah-masalah bagaimana mahluk hidup mengembangkan satu kehidupan yang 
lebih baik. IPA adalah pengetahuan yang mempelajari tentang keadaan dan kejadian alam secara sistematis, pengamatan, dan mengetahui fakta konsep penemuan dan sikap ilmiah. Pembelajaran IPA sudah di perkenalkan pada siswa sejak dari bangku taman kanak-kanak, karena pembelajaran IPA sangat penting bagi siswa karena melibatkan lingkungan siswa secara langsung (Rahayu, 2021).

Dari uraian latar belakang yang telah di paparkan, untuk kepentingan evaluasi pelaksanaan kurikulum 2013 di SDN 060849 Medan, perlu dilakukan survei proses pembelajaran yang berbasis pendekatan saintifik (scientific approach) dalam kurikulum 2013 pada pembelajaran IPA. Survei akan dilakukan terhadap pembelajaran IPA di kelas V dan VI dengan menggunakan instrumen yang disusun oleh peneliti dan telah divalidasi oleh ahli. Untuk mendapatkan informasi yang lebih luas survei dilanjutkan dengan pembagian angket pada siswa serta wawancara mendalam (indept interview) dengan guru (praktisi).

\section{METODE}

Penelitian dilakukan di SDN 060849 Medan yang bertempat di Jalan Karya Kecamatan Medan Barat. Populasi dari penilitian ini adalah guru IPA kelas V dan VI yang berjumlah 1 orang yang berpendidikan S1 dan siswa kelas V dan VI yang mempelajari mata pelajaran IPA sebanyak 138 siswa. Sampel pada penelitian ini diambil menggunakan teknik purposive sampling. Dasar pengambilan sampel adalah guru tersebut menggunakan pembelajaran dengan pendekatan saintifik (Scientific Approach), dan bersedia menjadi sampel sehingga pada penelitian ini yang menjadi sampel adalah guru IPA V dan VI yang berjumlah 1 orang.

Kelas pengamatan terdiri dari empat kelas, yaitu: kelas VA VB dan VIA VIB dengan jumlah siswa maksimal 20 orang per kelas. yang dijadikan sampel pada saat observasi tergantung pada jumlah siswa yang hadir dikarenakan hampir setiap pertemuan pembelajaran IPA jumlah hadir tidak tetap. Sementara siswa kelas V dan VI yang dijadikan sampel pengisan angket masing-masing diambil 20 Orang siswa dari masing-masing kelas objek. Untuk menjaga etika dalam penelitian, maka identitas guru diberi kode 1 sedangkan identitas siswa diberi kode dengan huruf kapital (A, B, C, dst...). Berdasarkan tempat duduk siswa dan tidak bersifat tetap karena pada saat proses pebelajaran yang berlangsung tempat duduk siswa selalu berubah-ubah.

Penelitian ini terdiri dari tiga tahap, yaitu: (1) Tahap Persiapan, (2) Tahap Pelaksanaan, dan (3) Tahap Analisis Data. Pada tahap persiapan, peneliti melakukan observasi awal ke sekolah untuk mengetahui permasalahan yang ada. Setelah itu peneliti menyusun proposal penelitian dan menyusun instrumen penelitian hingga divalidkan oleh ahli yaitu dosen. Pada tahap pelaksanaan, peneliti melakukan beberapa aktivitas berikut. 
1) Penilaian kesesuaian RPP yang disusun guru IPA kelas V dan VI SDN 060849 Medan yang akan digunakan pada saat pengamatan pembelajaran dengan menggunakan lembar penilaian kesesuaian RPP yang disusun guru dengan RPP berbasis kurikulum 2013 (Instrumen 01).

2) Pengamatan kegiatan pembelajaran IPA dengan Pendekatan Saintifik (Scientific Approach) di kelas V dan VI SDN 060849 Medan tahun pembelajaran 2019/2020 dengan menggunakan lembar observasi. Pengamatan dilakukan oleh peneliti beserta satu observer lain. Pengamatan dilakukan pada setiap kelas yang sedang melaksanakan pembelajaran IPA dengan pendekatan saintifik dengan jumlah total seluruh pengamatan sebanyak dua belas kali pengamatan. Pengamatan berfokus pada lima pengalaman belajar pendekatan saintifik dan kesesuaian pelaksanaan pembelajaran dengan RPP. Pengamatan dilakukan dengan menggunakan instrumen 02, instrumen 03, dan instrumen 04 .

3) Membagi angket (instrumen 05) kepada siswa kelas V dan VI SDN 060849 Medan tahun pembelajaran 2019/2020. Angket dibagikan setelah proses pengamatan pembelajaran berlangsung. Pembagian angket dilakukan satu kali. Angket dibagikan kepada seluruh siswa kelas V dan VI SDN 060849 Medan tahun pembelajaran 2019/2020.

4) Mewawancarai guru kelas V dan VI SDN 060849 Medan tahun pembelajaran 2019/2020 mengenai kendala dalam menerapkan pembelajaran berbasis Pendekatan Saintifik (Scientific Approach) sesuai instrumen wawancara. Wawancara dilakukan setelah kegiatan pengamatan dan pengisian angket dilaksanakan. Wawancara dilakukan dengan satu orang guru,yaitu guru IPA kelas V dan VI SDN 060849 Medan tahun pembelajaran 2019/2020.

5) Mengumpulkan informasi dari berbagai literatur untuk memberi solusi terhadap kendala yang dihadapi guru dalam pelaksanaan pembelajaran IPA berbasis Pendekatan Saintifik (Scientific Approach) dengan menggunakan instrumen 06 sebagai kendali.

6) Menganalisis data hasil penilaian RPP, hasil observasi, hasil wawancara, dan angket menggunakan teknik analisis deskriptif.

\section{HASIL}

\section{Kesesuaian Rencana Pelaksanaan Pembelajaran (RPP) Guru}

Dari hasil penilaian kesesuaian RPP yang disusun guru IPA kelas V dan VI diperoleh aspek yang kurang sesuai dengan RPP berbasis kurikulum 2013. Berikut adalah hasil penilaian kesesuaian RPP yang disusun oleh Guru IPA kelas V dan VI dapat dilihat pada tabel berikut. 


\section{Tabel 1}

Kesesuaian RPP guru dibandingkan dengan Unsur-unsur RPP kurikulum 2013

\begin{tabular}{|c|c|c|c|c|c|}
\hline \multirow[t]{2}{*}{ No } & \multirow[t]{2}{*}{ Aspek yang dinilai } & \multicolumn{2}{|c|}{ Nilai (\%) } & \multicolumn{2}{|c|}{ Rata - rata } \\
\hline & & $\begin{array}{l}\text { RPP } \\
\text { Kelas V }\end{array}$ & $\begin{array}{l}\text { RPP } \\
\text { Kelas VI }\end{array}$ & $\begin{array}{l}\text { Nilai } \\
(\%)\end{array}$ & Interpretasi \\
\hline 1 & Identitas RPP & 98 & 98 & 98 & Amat Baik \\
\hline 2 & Komponen utama RPP & 96 & 96 & 96 & Amat Baik \\
\hline 3 & Rumusan KI, KD. Dan IPK & 94 & 94 & 94 & Amat Baik \\
\hline 4 & Rumusan Tujuan Pembelajaran & 73 & 73 & 73 & Cukup \\
\hline 5 & Materi Pembelajaran & 71 & 71 & 71 & Cukup \\
\hline 6 & Metode Pembelajaran & 83 & 83 & 83 & Baik \\
\hline 7 & $\begin{array}{l}\text { Media Pembelajaran dan } \\
\text { Sumber Belajar }\end{array}$ & 95 & 95 & 95 & Amat Baik \\
\hline 8 & $\begin{array}{l}\text { Langkah Kegiatan } \\
\text { Pembelajaran }\end{array}$ & 91,3 & 91,3 & 82,1 & Baik \\
\hline \multirow[t]{2}{*}{9} & Penilaian Hasil Belajar & 92,73 & 93,73 & 92,73 & Amat Baik \\
\hline & Nilai Keseluruhan & 86,41 & 86,41 & 86,41 & Baik \\
\hline
\end{tabular}

Sumber: Dokumen pribadi penulis

Data tabel di atas menunjukkan bahwa kesesuaian RPP guru dibandingkan dengan RPP Kurikulum 2013 secara keseluruhan berada dalam ketegori Baik (8090). Aspek RPP yang berada di dalam kategori cukup (70-80) adalah rumusan tujuan pembelajaran, dan materi pembelajaran. Aspek RPP yang berada dalam kategori baik (80-90) adalah metode pembelajaran dan langkah-langkah kegiatan pembelajaran. Adapun aspek RPP yang berada dalam kategori amat baik (90-100) adalah identitas RPP, rumusan KI, KD, dan IPK, media pembelajaran dan sumber belajar, serta penilaian hasil belajar.

\section{Kesesuaian Pelaksanaan Pembelajaran dengan Rencana Program Pembelajaran (RPP) Guru}

Hasil penelitian ini menunjukkan bahwa kesesuaian pelaksanaan pembelajaran yang dilaksanakan oleh guru dibandingkan dengan rumusan RPP yang ditulisnya adalah sebagai berikut. 


\section{Tabel 2}

Kesesuaian Pelaksanaan Pembelajaran Dengan RPP

\begin{tabular}{lcccccc}
\hline Kegiatan & Kelas & Kelas & Kelas & Kelas & \multicolumn{2}{c}{ Rata-Rata } \\
\cline { 6 - 7 } & VA & VB & VIA & VIB & Nilai & Interpretasi \\
$\begin{array}{l}\text { Kegiatan } \\
\text { Pendahuluan }\end{array}$ & 91,23 & 86,18 & 86,18 & 91,23 & $89 \%$ & Baik \\
Kegiatan Inti & 78 & 82,87 & 81,93 & 81,44 & $80 \%$ & Baik \\
$\begin{array}{l}\text { Kegiatan } \\
\text { Penutup }\end{array}$ & 71,52 & 71,52 & 87,64 & 82,17 & $78 \%$ & Cukup \\
Keseluruhan & 80,62 & 81,47 & 82,56 & 84,32 & $82 \%$ & Baik \\
\hline
\end{tabular}

Sumber: Dokumen pribadi penulis

Tabel di atas menunjukkan bahwa kesesuaian penerapan pendekatan saintifik dibandingkan dengan RPP yang telah disiapkan oleh guru secara keseluruhan tergolong ke dalam kategori baik (80-90). Secara rinci, kegiatan pendahuluan dan inti memperoleh nilai baik dan kegiatan penutup memperoleh nilai cukup.

\section{Kelengkapan Unsur-unsur Pendekatan Saintifik di dalam Proses Pembelajaran}

Hasil pengamatan peneliti terhadap aktivitas siswa di dalam proses penerapan pendekatan saintifik adalah sebagai berikut.

\section{Tabel 3}

Kelengkapan Unsur-unsur Pendekatan Saintifik di dalam Proses Pembelajaran

\begin{tabular}{llcccccc}
\hline No. Kegiatan & Kelas & Kelas & Kelas & Kelas & \multicolumn{2}{c}{ Rata-Rata } \\
\cline { 6 - 7 } & & VA & VB & VIA & VIB & Nilai & Interpretasi \\
1. & Mengamati & $67 \%$ & $73 \%$ & $71 \%$ & $71 \% \%$ & $70 \%$ & Cukup \\
2. & Menanya & $25 \%$ & $34 \%$ & $18 \%$ & $18 \%$ & 24 & Kurang \\
& & & & & & $\%$ & \\
3. & Mengumpulkan & $60 \%$ & $61 \%$ & $50 \%$ & $66 \%$ & $60 \%$ & Kurang \\
& $\begin{array}{l}\text { informasi/ } \\
\text { Mencoba }\end{array}$ & & & & & & \\
4. & Mengasosiasi & $14 \%$ & $4 \%$ & $3 \%$ & $16 \%$ & $7 \%$ & Kurang \\
5. & Mengkomunikasi & $63 \%$ & $78 \%$ & $58 \%$ & $48 \%$ & $62 \%$ & Kurang \\
6. & $\begin{array}{l}\text { Pendekatan } \\
\text { Saintifik }\end{array}$ & $48 \%$ & $47 \%$ & $43 \%$ & $46 \%$ & $48 \%$ & Kurang \\
\hline
\end{tabular}

Sumber: Dokumen pribadi penulis 
Dominasi unsur-unsur pendekatan saintifik di dalam proses pembelajaran dapat dilihat dari grafik berikut.

\section{Gambar 1}

Rata-rata Nilai Pengalaman Belajar Pendekatan Saintifik Siswa

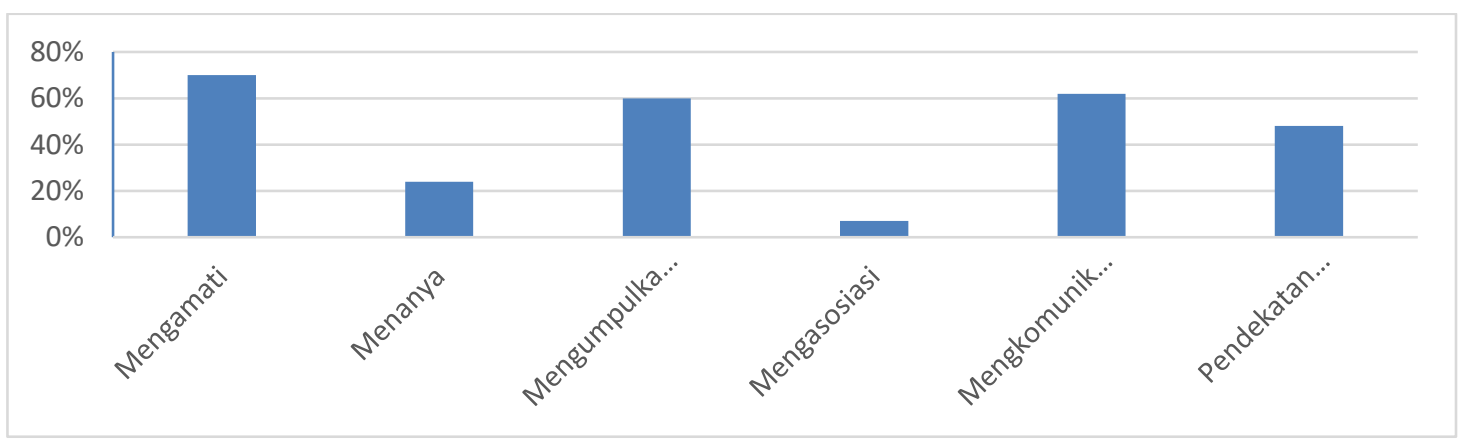

Sumber: Dokumen pribadi penulis

Grafik tersebut menunjukkan bahwa unsur-unsur pendekatan saintifik yang dominan adalah kegiatan mengamati dan yang tidak dominan (mengalami kendala) adalah kegiatan mengasosiasi.

\section{PEMBAHASAN}

Hasil wawancara yang dilakukan dengan guru kelas V dan VI memperoleh informasi bahwa guru telah melakukan persiapan sebelum melakukan pembelajaran, baik itu dari segi RPP, silabus dan media pembelajaran. Guru juga telah terbiasa menggunakan pendekatan saintifik walaupun dalam pelaksanaannya terdapat beberapa pengalaman belajar yang tidak dapat dilakukan sesuai dengan yang tercantum pada RPP.

Selain itu, kegiatan yang tercantum di RPP yang mempengaruhi kualitas pembelajaran juga masih ada yang tidak terlaksana, seperti penggunaan media pembelajaran. Menurut Sanjaya (2012) dengan melalui proses perencanaan yang matang, guru dapat memprediksi seberapa besar keberhasilan yang akan dicapai. Pembelajaran bukan hanya sekedar penyampaian materi pembelajaran, tapi suatu proses pembentukan perilaku siswa. Oleh karena itu, proses pembelajaran 
merupakan suatu yang kompleks dan harus diperhitungkan segala kemungkinannya, sebab segala kemungkinan tersebut perlu perencanaan yang matang dari setiap guru.

\section{Kesesuaian Rencana Program Pembelajaran (RPP) Guru dibandingkan denhan RPP Kurikulum 2013}

Hasil penelitian ini menunjukkan bahwa secara keseluruhan nilai presentase kesesuaian RPP yang disusun oleh guru IPA di SDN 060849 Medan dengan RPP berbasis kurikulum 2013 sudah termasuk pada kategori baik dengan nilai presentase 86,41\%. Namun pada beberapa komponen RPP yang merupakan aspek yang masih diamati pada penilaian ini terdapat beberapa aspek yang mendapat kategori cukup. Aspek pengamatan yang termasuk dalam kategori cukup adalah rumusan tujuan pembelajaran dengan presentase nilai sebersar $73 \%$ dan materi pembelajaran dengan presentase nilai sebersar 71\%. Aspek penilaian yang termasuk dalam kategori baik yaitu metode pembelajaran dengan presentasi nilai sebesar 83\% serta langkah kegiatan pembelajaran dengan presentase nilai 82,1\%. Aspek yang termasuk dalam kategori amat baik yaitu identitas RPP, rumusan KI, KD, dan IPK, media pembelajaran dan sumber belajar, dengan presentase nilai masingmasing 98\% dan penilaian hasil belajar dengan presentasi senilai 94\%.

Adanya komponen RPP yang memiliki cukup dikarenakan terdapat beberapa hal yang seharusnya terdapat pada RPP yang akan digunakan guru berdasarkan tuntutan Kurikulum 2013, namun tidak tampak pada RPP tersebut. Rumusan tujuan pembelajaran dan materi pembelajaran merupakan aspek yang mendapatkan presentase cukup. Pada rumusan tujuan guru hanya menulis poin-poin tujuan pembelajaran tanpa dirumuskan. Tujuan pembelajaran merupakan arah atau sasaran dari suatu kegiatan pembelajaran, oleh karena itu rumusannya harus jelas dan lengkap (mengandung unsur audience, behaviour, condition, dan degree) serta dirumuskan dari KD dalam kurikulum. Rendahnya perolehan nilai kesesuaian pada aspek rancangan penilaian pembelajaran pada penilaian ini sesuai dengan hasil penelitian yang pernah dilakukan oleh Asarina (2014) ditemukan guru kesulitan membuat dan mengembangkan instrumen penilaian pembelajaran. Selain itu pada materi pembelajaran, guru tidak melampirkan seluruh materi pembelajaran didalam RPP, guru hanya menuliskan poin-poin saja.

\section{Kesesuaian antara Pembelajaran yang dilakukan dengan Rencana Pelaksanaan Pembelajaran (RPP)}

Hasil penelitian ini menunjukkan bahwa rata-rata kesesuaian pelaksanaan pembelajaran IPA dengan RPP memperoleh nilai 82\% secara keseluruhan dengan inteprestasi baik. Pada kegiatan pendahuluan dan inti rata-rata pelaksanaan baik sesuai dengan RPP dengan perolehan nilai masing-masing 89\% dan 80\% namun pada kegiatan penutup diperoleh pelaksanaan cukup sesuai dengan RPP dengan perolehan nilai 78\%. Pada kegiatan pendahuluan hal yang pernah tidak 
dilaksanakan guru yang tercantum pada RPP adalah melakuakan atau apersepsi, mengaitkan pengetahuan yang sebelumnya dengan materi yang kan datang, dan menampilkan dalam bentuk gambar dengan proyektor.

Rencana pelaksanaan pembelajaran pada kegiatan pendahuluan yang merupakan kegiatan pembukaan pada pempelajaran yang sudah dirancang dengan baik tidak dapat terlaksana sesuai dengan perencanaan menyebabkan pelaksanaan pembelajaran tidak begitu maksimal merutu Sanjaya (2012), membuka pembelajaran untuk menciptakan prakondisi bagi siswa agar mentalmaupun perhatian terpusat pada pengalaman belajar yang disajikan sehingga akan mudah mencapai kompetensi yang diharapkan. Dengan kata lain, membuka pembelajaran itu adalah mempersiapkan mental dan perhatian siswa agar siswa terpusat pada hal-hal yang akan dipelajari.

Pada kegiatan inti guru IPA kadang tidak melaksanakan kegiatan memberi siswa suatu permasalahan peranan animalia pada setiap kelompok pada tahap mengasosiasi sedangkan guru kadang tidak membagikan LKS pada siswa dikegiatan mengasosiasi hal-hal tersebut menyebabkan kegiatan selanjutnya yang merupakan lanjutan dari kegiatan tersebut juga tidak dapat terlaksana sehinggan memnyebabkan tujuan pembelajaran tidak tercapai seluruhnya terutama pada tahap mengasosiasi.

Pada kegiatan penutup guru terkadang tidak membimbing siswa untuk menyimpulkan pembelajaran dan tidak memberikan soal tertulis kepada siswa. Guru IPA juga terkadang tidak memberikan tugas tertulis pada akhir pembelajaran, dan terkadang tidak sempat menyimpulkan materi pembelajaran hal ini disebabkan karena waktu yang tidak mencukupi berdasarkan tabel 4. diperoleh nilai rata-rata pelaksanaan kegiatan penutup termasuk kedalam interpretasi yang cukup, padahal kegiatan penutup merupakan kegiatan untuk merefleksi sejauh mana tujuan pembalajran tercapai, sesuai dengan pernyataan Sanjaya (2012), menutup pembelajaran dapat diartikan segai kegiatan yang dilakukan guru untuk mengakhiri pelajaran dengan maksud untuk memberikan gambaran menyeluruh tentang apa yang telah dipelajari siswa terkait keberhasilan siswa, serta keberhasilan guru dalam pelaksanaan pembelajaran.

Presentase kesesuaian pelaksanaan pembelajaran dengan RPP guru yang memperoleh nilai baik, akan tetapi hal tersebut dikatakan kurang maksimal. Perencanaan yang kurang maksimal dapat terlihat pada penilaian RPP yang akan digunakan oleh guru. Pada table 3. dapat dilihat bahwa masih terdapat aspek yang kurang sesuai dengan RPP berbasis kurikulun 2013 yaitu pada perumusan tujuan pembelajaran. Seharusnya tujuan pembelajaran harus disusun dengan baik dan benar karena tujuan pembelajaran merupakan arah atau sasaran dari suatu kegiatan pembelajaran. Nilai kesesuaian memperoleh kategori baik sesuai terdapat pada aspek perumusan indikator pembelajaran dan rancangan penilaian 
pembelajaran. Rancangan penilaian pembelajaran yang tidak maksimal menyebabkan kegiatan penilaian tidak terlaksana dengan baik pada saat pembelajaran. Menurut Harianto (2009), perencanaan yang baik sangat membantu pelaksanaan pembelajaran. Dalam pembelajaran akan dibutuhkan komitmen yang kuat untuk menerapkan perencanaan yang telah dirancang dengan baik.

\section{Kelengkapan Unsur-unsur Pendekatan Saintifik di dalam Proses Pembelajaran}

Hasil penelitian ini menunjukkan bahwa bahwa aktivitas pengalaman belajar pendekatan saintifik siswa secara keseluruhan mendapatkan nilai rata-rata $48 \%$ dengan interpretasi kurang. Urutan pengalaman belajar pendekatan saintifik dari yang paling banyak dilakukan siswa hingga yang paling sedikit dilakukan siswa adalah mengamati, mengumpulkan informasi, mengkomunikasikan, menanya dan mengasosiasi. Dari lima pengalaman belajar saintifik, pengalaman belajar yang paling dominan dilakukan oleh siswa adalah mengamati dengan perolehan presentase siswa yang melakukan sebanyak 70\% dengan interprestasi cukup.

Adapun bentuk-bentuk pengalaman belajar yang dilakukan siswa selama melakukan pengalaman belajar mengamati yaitu, membaca buku atau sumber belajar lain, mendengarkan penjelasan guru, mendengarkan presentase yang dilakukan oleh siswa lain, mengamati gambar, mengamati video pembelajaran, mengamati morfologi dan anatomi ikan mas secara langsung. Bentuk-bentuk pengalaman belajar yang difasilitasi oleh guru dan dilakukan oleh siswa ini merupakan bentuk pengalaman belajaran yang memang seharusnya ada pada proses melakukan pengalaman belajar mengamati, sesuai dengan pernyataan kosasih (2014), langkah pertama dalam proses pembelajaran saintifik adalah mengamati. Prosesnya dapat dilalui melalui membaca sumber-sumber tertulis, mendengar informasi lisan, melihat gamber dan sejenisnya, menonton tanyang, dan menyaksikan fenomena alam, sosial, dan budaya.

Bentuk pengalaman belajar yang dialami oleh siswa pada tahap mengamati adalah membaca mendengar, menyimak dan melihat. Bentuk-bentuk pengalaman belajar tersebut merupakan bentuk pengalaman belajar yang memang seharusnya dilakukan oleh siswa pada saat mengamati. Sebagaimana disampaikan dalam permendikbud 81A, hendaklah guru membuka secara luan dengan bervariasi kesempatan serta didik untuk melakukan pengamatan melalui kegiatan: melihat, menyimak, mendengar dan membaca.

\section{Kendala Guru dalam Menerapkan Pendekatan Saintifik}

Hasil penelitian ini menunjukkan bahwa pengalaman belajar yang paling tidak dominan (mengalami kendala) dilakukan selama proses pengamatan pembelajaran IPA di SDN 060849 Medan adalah kegiatan mengasosiasi. Hasil ini sesuai dengan hasil temuan Astuti (2016) yang mengatakan bahwa kegiatan mengasosiasi masih kurang maksimal dilakukan pada proses pembelajaran. Jika dihubungkan dengan 
kesesuaian pelaksanaan pembelajaran dengan RPP, terdapat beberapa kegiatan dalam tahap mengasosiasi yang tidak dilaksanakan oleh guru, pada kelas $\mathrm{V}$ pembebrian masalah mengenai peranan animalia pada kehidupan sehari-hari kepada setiap kelompok tidak dilaksanakan oleh guru dan pada kelas VI pembagian LKS yang berisi langkah-langkah kegiatan dan masalah yang berkaitan dengan sistem reproduksi sama sekali tidak dilaksanakan oleh guru. Padahal kegiatan tersebut merupakan kegiatan yang sesuai untuk membuat siswa mengasosiasi, seperti yang dinyatakan oleh Sani (2014) salah satu strategi yang dapat dilakukan sebagai upaya untuk melatih siswa dalam merupakan penalaran adalah melatih siswa untuk dapat memberikan solusi menyelesaikan suatu permasalahan.

Berdasarkan hasil wawancara dengan guru-guru IPA didapatkan bahwa mengasosiasi merupakan pengalaman belajar pendekatan saintifik yang paling jarang dilaksanakan dikarenakan keterbatasan waktu yang tersedia dan beberapa hal yang menyebabkan penggunaan waktu yang kurang efektif, seperti tidak semua siswa memiliki buku pegangan dan masih banyak murid yang malu-malu serta tidak aktif untuk mengeluarkan pendapat ketika diberi pertanyaan mengenai hal-hal yang berkaitan dengan penerapan materi yang telah dipelajari.

Berdasarkan uraian dimuka, dapat disimpulkan bahwa bentuk-bentuk kegiatan pada pengalaman belajar mengasosiasi yang tidak dominan (merupakan kendala) dalam pembelajaran IPA adalah mengerjakan latihan dengan panduan LKS karena LKS tidak dibagikan oleh guru, menyimpulkan hasil pembelajaran dikarenakan penggunaan waktu yang kurang efektif dan siswa yang tidak percaya diri dan kurang aktif. Hal ini sesuai dengan hasil penelitian yang dilakukan oleh Muliatina (2016) yang menyatakan penyebab kendala yang dihadapi guru dalam kegiatan mengasosiasi adalah kurangnya motivasi guru terhadap perserta didik dan penggunaan waktu yang kurang efektif.

\section{Strategi Untuk Megatasi Kendala Penerapan Pendekatan Saintifik}

Berdasarkan uraian sebelumnya diketahui beberapa kendala pada pelaksanaan pembelajaran IPA berbasis pendekatan saintifik yaitu, (1) Siswa yang aktif dan malu-malu; (2) penggunaan waktu yang kurang efektif; (3) kurangnya persiapan oleh guru. Adapun solusi-solusi untuk mengatasi kendala-kendala tersebut adalah sebagai berikut:

1) Cara mengatasi siswa yang tidak aktif

Siswa yang tidak aktif dalam proses pembelajaran dapat diatasi dengan penggunaan media pembelajaran. Poerwanti (2010), menyatakan bahwa penggunaan media konkret dapat meningkatkan aktivitas belajar siswa. Selain meningkatkan aktivitas siswa, motivasi belajar siswa juga dapat ditingkatkan melalui media pembelajaran sesuai dengan hasil penelitian Kartikasari (2016), didapatkan bahwa terdapat pengaruh yang signifikan penggunaan media penggunaan pembelajaran terhadap motivasi belajar siswa. Menurut Suyanto 
(2013) penggunaan media dapat dikaitkan dengan konsep, pemahaman konsep, latihan dan penguatan, pelayanan terhadap perbedaan kemampuan individual, pemecahan masalah pada umumnya, rangsangan untuk berfikir, rangsangan untuk berdiskusi, serta rangsangan untuk berpartisipasi aktif. Selain itu keaktifan belajar siswa dapat ditingkatkan dengan melakukan pemberian reward kepada siswa, sesuai dengan hasil penelitian Jannah (2013) didapatkan bahwa pemberian reward berpengaruh positif terhadap keaktifan belajar siswa dalam mengikuti pelajaran.

Siswa yang tidak aktif dalam mengasosiasi disebabkan kurang tersedianya kegiatan untuk mengasosiasi sehingga siswa perlu dilatih untuk melakukannya. Menurut Sani (2014), upaya untuk melatih siswa dalam melakukan penalaran dapat dilakukan dengan meminta siswa untuk menganalisis data yang telah diperoleh sehingga mereka dapat menemukan hubungan antar variabel, atau dapat menjelaskan tentang data berdasarkan teori yang ada, menguji hipotesis yang telah diajukan, dan membuat kesimpulan.

Beberapa strategi yang dapat dilakukan adalah: (1) melatih siswa untuk memberikan argumen yang utuh terhadap temuan atau data yang diperoleh, sesuai dengan permasalahan yang dikaji, (2) melatih siswa untuk menganalisis, mensintesis, mengevaluasi, membuat generalisasi, dan menarik kesimpulan; (3)melatih siswa untuk dapat memberikan solusi atau menetapkan beberapa penyelesaian alternatif yang dapat dilakukan untuk menyelesaikan suatu permasalahan.

2) Cara mengatasi penggunaan waktu yang kurang efektif

Kendala dalam mengatasi penggunaan waktu yang kurang efektif yang diakibatkan kurangnya sumber belajar dapat diatasi dengan solusi pemberian referensi oleh guru sehingga siswa tidak berpatok pada buku cetak atau internet saja. Menurut Kosasi (2016), agar siswa dapat melakoni kegiatan mengasosiasi guru harus memfasilitasi siswa dengan menyediakan sejumlah referensi dan latihan yang bisa memperkaya dan memperdalam pemahaman mereka terkait KD yang sedang dikembangkan.

3) Cara mengatasi kurangnya persiapan guru

Kurangnya persiapan guru tampak dari tidak selalu tersedianya yang seharusnya ada pada saat mengasosiasi, selain itu media pembelajaran juga tidak selalu ada seperti yang tercantum pada skenario RPP. Untuk mengatasi kesulitan guru dalam mempersiapkan bahan ajar, solusi yang dapat dilakukan adalah dengan bekerjasama dengan guru lain, teman sejawat untuk mempersiapkan bahan ajar atau perangkat pembelajaran, sesuai dengan hal yang dikemukakan Kinasih (2017), bahwa upaya guru untuk mengatasi permasalahan dalam menyusun perangkat pembelajaran adalah debgan diskusi teman sejawat menggunakan media pembelajaran yang sederhana dan media sudah tersedia di sekolah. 


\section{SIMPULAN}

Hasil evaluasi kesesuaian RPP guru menggunakan instrumen penilaian RPP kurikulum 2013 berbasis pendekatan saintifik telah memperoleh nilai persentase sebesar 86,41\%, yaitu tergolong ke dalam kategori baik. Hasil evaluasi kesesuaian pembelajaran yang dilaksanakan oleh guru dibandingkan dengan RPPnya sevara keseluruhan berada pada kategori baik.

Unsur pendekatan saintifik yang paling dominan dilakukan oleh siswa kelas $\mathrm{V}$ dan VI adalah kegiatan mengamati dengan presentase sebesar 70\%. Bentuk-bentuk pengalaman belajar siswa adalah membaca, mendengar, menyimak dan melihat. Kendala dalam penerapan pendekatan saintifik adalah dalam menerapkan kegiatan asosiasi. Strategi guru untuk mengatasi masalah penerapan kegiatan asosiasi adalah dengan melatih siswa memecahkan masalah, berargumen, memfasilitasi siswa dengan media pembelajaran; memberikan reward, menyediakan sumber belajar tambahan, dan mendorong siswa berdiskusi dengan teman sekelasnya.

Hasil penelitian ini menyarankan kepada guru untuk mempersiapkan sumber belajar, media ajar dan kegiatan belajar yang sesuai dengan RPP, serta mengikuti pelatihan. Keterbatasan penelitian ini adalah pada durasi waktu observasi yang kurang panjang dan jumlah guru yang diteliti juga masih sangat sedikit.

\section{DAFTAR PUSTAKA}

Andriani, N. (2018). Survei Pemetaan Proses Pembelajaran IPABerbasis Pendekatan Saintifik (Scientific Approach) Di SMA Muhammadiyah 1 Medan T.P 2017/2018. J, 1(1), 1-8.

Asarina, R., (2014), Studi Eksplorasi Kendala-Kendala Guru Dalam Pembelajaran IPS Di SMP Wilayah Kecamatan Moyudan, Jurusan Pendidikan ILMU Pengetahuan Sosial, Universitas Negeri Yogyakarta, Yogyakarta

Astuti, L, D., (2016) Analisis Pelaksanaan Pembelajaran Matematika Materi Transformasi dengan pendekatan Saintifik Kurikulum 2013 di Kelas VII smp Negeri 2 Wedi Tahun Ajaran 2015/2016, Skripsi, Jurusan Pendidikan Matematika dan Ilmu Pengetahuan Alam, Universitas Sanata Dharma, Yogyakarta

Hariyanto, D., (2009), Kinerja Guru Kejujuran yang telah bersertifikat Pendidik di SMKN Se-Kota Malang, Universitas Negeri Malang: Malang

Jannah, A., (2013), Pengaruh Pemberian Reward Guru Terhadap Keaktifan Belajar Siswa Kelas XI Dalam Mengikuti Pelajaran Al-Quran Hadits MAN Tengaran Kab. Semarang Tahun Pelajarn 2013, Skripsi, Jurusan Tarbiyah, SekolahTinggi Agama Islam Negeri Salatiga, Salatiga

Kartikasari, Galuh., (2016), Pengaruh Media Pembelajaran Berbasis Multimedia Terhadap Motivasi dan Hasil Belajar Materi Sistem Pencernaan Manusia Studi 
Eksperimen Pada Siswa Kelas V MI Miftahul Huda Pandantoyo, Dinamika Penelitian, 16 (1): 59-77

Kinasih, A,R., (2017), Problematika Guru Dalam Penyusunan Perangkat Pembelajaran Di SD Muhammadiyah 14 Surakarta, Program Studi Pendidikan Guru Sekolah Dasar, Universitas Muhammadiyah Surakarta, Surakarta

Kosasih,E., (2014), Strategi Belajar dan Pembelajaran Implementasi Kurikulum 2013, Yrama Widya, Bandung

Mudana, I. G. A. M. G. (2020). Pembelajaran Literasi Melalui Pendekatan Saintifik Dalam Mata Pelajaran Bahasa Indonesia Di Sekolah Dasar. 2, 1-10.

Muliatina, (2016), Kendala Guru Dalam Menerapkan Pendekatan Saintifik pada Kurikulum 2013 di SDN Teupin Pukat Meureudu Pidie Jaya, JurnalI Imiah Mahasiwa Prodi PGSD FKIP Unsyiah1 (1): 129-136

Nureva, \& Melinda, M. (2021). The Influence of Scientific Approach on the Result of Learning Natural Science in Class VSD Negeri 1 Segalamider at Bandar Lampung. 1(1), 1-6.

Purwanti, L., (2010) Peningkatan Aktivitas Pembelajaran IPA Dngan Media Benda Konkret Pada Siswa Kelas II SDN 01 Kaling Tasikmadu Karanganyar Tahun 2009/2010, Skripsi, FKIP, Universitas Sebelas Maret, Surakarta

Rahayu, A. S. R. I. (2021). Penerapan Strategi Everyone Is A Teacher Here dalam Meningkatkan Minat Belajar IPA Pada Siswa Kelas V SD Inpres Borong Jambu II Kota Makassar.

Sani, R.A., (2014). Pembelajaran Saintifik untuk Implementasi Kurikulum 2013. Jakarta: PT BumiAksara

Sanjaya, W., (2008), Kurikulum dan Pengembangan Teori dan Praktik Pengembangan KTSP, Kencana Prenada Media Group, Jakarta.

Saputra, V. H. (2021). Komik Berbasis Scientific Sebagai Media Pembelajaran di Masa Pandemik Covid-19. 5(1), 85-96. https://doi.org/10.35706/sjme.v5i1.4514

Sudaryono., Margono, G., dan Rahayu, W., (2012), Pengembangan Instrumen Penelitian Pendidikan, Graha Ilmu, Tangerang

Suratno. (2020). Upaya Peningkatan Kemampuan Guru Sd Negeri 01 Sungai Ringin Dalam Menerapkan Pembelajaran Pendekatan Saintifik Melalui In House Training (Iht). 7(1), 107-115.

Suyanto dan Asep, J., (2013), Menjadi Guru Profesional Strategi Meningkatkan Kualifikasi dan Kualitas Guru di Era Global, Erlangga, Jakarta. 